\title{
FACTORS CAUSING FOREIGN LANGUAGE ANXIETY (FLA) IN SPEAKING
}

\author{
Alheru Akbar \\ University of Bengkulu \\ Alheru.akbar17@gmail.com \\ Dedi Sofyan \\ University of Bengkulu \\ Dedisofyan73@gmail.com \\ Indah Damayanti \\ University of Bengkulu \\ Indah_078@yahoo.com
}

\begin{abstract}
This research attempted to find out the factors causing foreign language anxiety in speaking. This research was carried out by employing descriptive quantitative design. The population of this research was the third semester students of English Education Study Program of University of Bengkulu in academic year 2017/2018. The samples of this research were taken by using total sampling tehcnique, i.e 79 students. The data were collected by questionnaire consisted of 29questions related to the anxiety. The results of this study showed that the students mostly had the anxiety. There were three factors that causing the anxiety of the students in speaking; Test Anxiety (Mildly Affected; Mean Score: 3.09), Fear of Negative Evaluation (Mildly Affected;Mean Score: 3.00), and Communication Apprehension (Mildly Affected; Mean Score: 2.90). In conclusion, there were three factors that causing the student' anxiety in speaking, and the most dominant factors is the Test Anxiety. In addition, from the test anxiety, it was found that mostly students were afraid of the consequences failing their speaking class.
\end{abstract}

Keywords: Foreign Language Anxiety, Speaking.

\section{INTRODUCTION}

In Indonesia, Bahasa Indonesia is country's official language and it is predominantly used in government, social life and education. The use of English has been increasing in our educational system which is shown by the effort of Ministry of Education in making education in Indonesia be familiar with English subject. As the matter of fact, English is introduced since students in elementary school as an additional course until itbecomes a major subject in junior high school and senior high school. Moreover, in certain kindergarten. Basic English for children

has been introduced to the students to make the students familiar with English as well. So that, by learning English, studentsare expected to have a great improvement in English skillafter they graduate from senior high school, especially in speaking skill.

Currently, in University, English Department Students learn English as their major subject, but it still categorized as a foreign language. Hence, even if they are the students of English Study Program, they arestill rarely using English as their daily language to communicate with the 
others both in classroom and outside the classroom. Within the classroom itself, foreign language learning can be affected by anxious feelings especially when the learners do not achieve adequate proficiency in their speaking.

This anxious feeling is known as Foreign Language Anxiety (FLA). According to Macintyre and Gardner (1994), foreign language anxiety is the feeling of tension and apprehension specifically associated with second language contexts, including speaking, listening, and learning. According to Horwitz (2001), this is different from a general feeling of anxiety, and therefore it keeps learners from reaching their goals. Foreign language anxiety as a distinct complex of selfperceptions, beliefs, feelings, and behaviors related to classroom language learning arising from the uniqueness of the language learning process. From this perspective, they claimed that language anxiety is unique due to the way it involves learners' self-concepts to communicate competently and to present themselves genuinely. There are so many factors that caused this kind of anxiety, as what has been divided by Horwitz, Horwitz\& Cope (1986). First, communication apprehension which arises from learners' inability, that they cannot adequately express mature thoughts and ideas. Second, fear of negative social evaluation, which arises from a learner's need to make a positive social impression on others. Third, test anxiety,anapprehension about academicevaluation.

Based on the classification that has been explained above, it becomes the consideration and quite interesting to be analyzed. As the researcher assume, this anxiety occurs among3rd semester students of English Education Study Program. Specifically, this anxiety mostly can be figured out in their speaking ability becausespeaking is ability that directly relate to the ability of the students in expressing their thought and ideas. Elaldi (2016) stated that learners sometimes got the anxious feeling because they are required to have a high standard as same as the standard of native speaker that they have found. Kitano (2001) stated that foreign language learners are exposed to the expert language of native speakers from tapes, videos and instructors. Because of that reason, many learners are afraid to speak out their mind in front of public, because they expected themselves to bethe standard that they have set by their own and believe they would not achieve an appropriate fluency in speaking. Rajanthran(2013) explained that the fear of falling short of these expectations can hinder the learning. According to Young (1999) anxious learners think that their language skills, especially speaking skills, are weaker than their peers' because of perceiving speaking ability as the most important.

The researcher is focusing the case of anxiety that often occurs in classroom. Woodrow (2006) draws a distinction between in-class and out-of-class anxiety and finds that communication with teachers and performing in front of a class are the major contributors to language anxiety in speaking classes. It is shown when students are given the tasks to do oral presentations, role-play in front of class, contribution to formal discussions, answering teacher questions, informally speaking teachers were reported. All those tasks are predicted as the major reasons for learners' in-class anxiety.

Based on what Maclntyre (1999) examined, the effects of language anxiety are divided into four categories: academic effects, cognitive effects, social effects and personal effects. In general,the kind 
of language anxiety that occurs among the students in classroom is the social effect where the atmosphere of the class sometimesdrives the students into a competition. According to Kayaoglu and Saglamel(2013) in a competition, learners constantly compare themselves with the ones superior to them, thus losing their enthusiasm or sometimes giving up the task or avoiding the task.

Otherwise, some researchers also believe that anxiety can bring a good motivation as the positive impact towards the students. Abderrezag (2010) examined that anxiety can also have debilitative and facilitative forms. Whereby, stress can be a good motivator for the students. It may keep students in alert and provide them with a motivation. In contrast some stress can have devastating impact and can lead students forget several issues during an exam. This positive anxiety called facilitating anxiety and the negative called debilitating one. The former does not inhibit the preparation for tests and exams, and can motivate the learner to learn and succeed.

In addition,Scovel as cited in Ellis (1994) explained that facilitating-anxiety keeps learner motivated and "fight" new information and pushing them to do more effort to reduce the negative impact of anxiety. Along with Scovel, Dörney (2005) concluded that anxiety does not only hinder achievement but some other way it improves and develops it.

Based on the reason above, the research her believes that the case of foreign language anxiety is worth to be analyzed, $\mathrm{He}$ assume that there are several factors causing foreign language anxiety in speaking classroom.

This research had two research questions which were:
1. What are the factors that causing foreign language anxiety in speaking classroom?

2. What is the most dominant factor causing foreign language anxiety in speaking classroom?

The researcher hopes this research will give some influences for some group of people such as, the students, the teachers or lecturers, and future researches.

\section{METHOD}

This study employed a descriptive quantitative design. According to Arikunto (2010), quantitative research is an attempt to investigate an issue by using numerical data and statistical processing. Descriptive method is to find the answer of questions and to test hypothesis concerning the current situation of the subject of the research when there is certain phenomenon or situation happened (Gay, 1987).Susetyo (2015) stated that descriptive quantitative research design is conducted to investigate the actual problem that is currently happened. The description of the causes of students' anxiety was explored using this method. It offers deep insight to see the issue experienced by the participants (Maxwell, 1996).

The population of this research is third semester students in English study program in academic year 2017/2018. The total is 2 classes: class A and B. Total number of population is 79students. The researcher chooses this population, because semester third students of English study program has experienced quite long learning process, and also they have been learning with several lecturers who graduated from universities in abroad which influenced their learning process and also their anxiety. 
Another reason why the researcher chooses the semester third students from different classes as the sample, because based on the researcher experience semester third have a quite longer experience in learning English, so they may also have experienced the anxiety of learning foreign language.

Arikunto (2010) stated that if the population is less than 100 respondents, it is better for the researcher to take all of the population as sample. Meanwhile, if the population is more than 100 respondents, the researcher may take 10$15 \%$ or $20 \%-25 \%$ from the total population as sample. In this research, the researcher will take all the students which consist of 80 students.

In this research the researcher will use two instruments to collect the data. First is questionnaire which will be used to measure the level of anxiety as well as the possible factors that are affected the anxiety. Second, the researcher will doingdepth interview to confirm the major cause of the anxiety that happened among the students.

The questionnaire form adapted and modified from Foreign Language Classroom Anxiety Scale (FLCAS) that developed byHorwitz al. (1986).This questionnaire has the function to measure the level of anxiety perceived by foreign language learners. FLCAS have 33 items but in order to make it more relatable to the background of the students of English Department in University of Bengkulu, the researcher make several changes helped by the expert who are done the validation of the questionnaire.After modified, the questionnaire only consist 29 questions from 33 questions.TheFLCAS questionnaire is consists of two statements which are positive and negative. The positive range will be ranged from 5-1 as represent "Strongly
Disagree" to "Strongly Agree". While, the negative statement will be ranged from 15 as represent "Strongly Agree" to "Strongly Disagree". There are 11 positive statements in the questionnaire which are number $2,5,8,11,14,18,20,22,24,28$, and 29. While, the negative statements are in number $1,3,4,6,7,9,10,12,13$, $15,16,17,19,21,23,25,26$, and 27 . The data were calculated manually with the range of score started from 29 to 145. After the each score from students' results of FLCAS gained, it was categorized into some levels of anxiety started from "Very Anxious", "Anxious", "Mildly Anxious", "Relaxed", and "Very Relaxed" based on Oetting's scale.

After the questionnaire is given and their level of anxiety has been measured as the students with middle to high anxiety level. Several students will be taken as the respondent to be interviewed in order to confirm what the major causes that make them feeling anxious are, in order to perform a spoken language in classroom. The interview will use an Open-Ended interview in order to dig deeper the information from the students who have the high level of anxiety.

To collect the data from the subject, the researcher distributed the questionnaires adapted by Horwitz et al. (1986). The FLCAS questionnaire administered to the third semester English Department student. After that, the administered questionnaire will be collected and the data from questionnaire will be analyzed, the obtained data has been described in the descriptive-quantitative form. Then the researcher found the frequency of the students' anxiety level and factors that are affected the anxiety.

After collecting the data, the researcher analyzed the data. To find the students' level of anxiety, the weighted formula is used 
Where

$$
\mathrm{M}=\frac{\sum F \cdot W}{N}
$$

$M$ : The weighted mean score of each statement

W : Weighted number of score each statement

$\Sigma \mathrm{F}$ : Total frequency of respondents who choose alternative answer

$\mathrm{N}$ : Weight/score of each alternative answer

The mean of the score for the items of the whole group were finding out by applying the following formula:

$$
\mathrm{Mg}=\frac{\Sigma \mathrm{M} . \mathrm{N}}{\Sigma N}
$$

Where:

$\mathrm{Mg}=$ the mean of the score of the whole statement for a group

$M=$ Mean score of each statement

$\mathrm{N}=$ Frequency of respondents answering

\begin{tabular}{|c|c|c|}
\hline $\begin{array}{l}\text { Number of } \\
\text { Students }\end{array}$ & Percentage & Category/Predicate \\
\hline 1 & $1.27 \%$ & Very Anxious \\
\hline 5 & $6.33 \%$ & Anxious \\
\hline 62 & $78.48 \%$ & Mildly Anxious \\
\hline 8 & $10.12 \%$ & Relaxed \\
\hline 3 & $3.80 \%$ & Very Relaxed \\
\hline
\end{tabular}
each statement

$\Sigma \mathrm{N}=$ Number of all respondents

There are six steps that used to make score interpretation, namely:

a) Make five categories of frequencies, namely: very anxious, anxious, mildly anxious, relaxed and very relaxed.

b) Determine the highest score with the lower score to find the range of score $(r)$ $r=5-1=4$

c) Divide the range with the number of category to find the length of class category $(p)$

$p=4 / 5=0.8$

d)Find the lowest classes.
e)Add the lowest class with $p(0.8)$ to find the highest score of the class, example: $1+0.8=1.8$

f)Define the table of frequency category.

There were some steps researcher did in conducting this research. The procedures as follow:

1.The researcher consulted all the activity related to this research with the supervisor and co-supervisor.

2.The researcher constructed the instruments of this research (questionnaire)

3. The researcher stated the subject of this research.

4. The researcher tried out the instrument (questionnaire)

5. The researcher took the data by giving questionnaire to the subject.

6. After gathering the needed data, the researcher analyzed them by using the formula and described the data.

\section{RESULTS AND DISCUSSION RESULTS}

After analyzing the data, the researcher found that the percentages of the students who have the anxious feeling, as shown in this table below:

TABLE I. The result of students' anxiety level

From the represented data in table, the result were as follows, 1 student (1.27\%) was indicated in "Very Anxious" level, 5 students (6.33\%) were indicated in "Anxious" level, 62 students (78.48\%) were indicated in "Mildly Anxious" level, 8 students (10.12\%) were indicated in "Relaxed" level, and 3 students (3.80\%) were indicated in "Very Relaxed" level. The data indicate that the majority of the students (62 out of 79) were in the level of Mildly Anxious, which also indicated that overall anxiety level of the Third Semester student is Mildly Anxious. 
In the part of data collection, the researcher had found the factors causing the students were failing into anxiety states. The researcher divided the result into three major causes; Test Anxiety, Communication Apprehension, and Fear of Negative Evaluation. The results of this research were presented as follows:

TABLE II. The Result of Factors that Causing Students' Anxiety in Speaking

\begin{tabular}{|l|l|l|}
\hline No & Speaking Anxiety Group & $\begin{array}{l}\text { Mean } \\
\text { Scores }\end{array}$ \\
\hline 1 & Test Anxiety & 3.09 \\
\hline 2 & $\begin{array}{l}\text { Communication } \\
\text { Apprehension }\end{array}$ & 2.90 \\
\hline 3 & $\begin{array}{l}\text { Fear of Negative } \\
\text { Evaluation }\end{array}$ & 3.00 \\
\hline
\end{tabular}

As the table above, it could be concluded that the most factors that causing the student anxiety was the Test Anxiety with mean score 3.09. It meant the sources of the student anxiety mostly came from the test; it was also supported from the interview data in which most of the respondents told they were so nervous when they were asked to speak in front of the class.

The Test Anxiety became the main sources of the anxiety state level that felt by the students. The detail explanation where divided into several expalanation from each item from the questionnaire. But there were three items that had strongly affected the students. Which were:Item number 10;I worry about the consequences of failing my speaking class. From 79 respondents, 1 respondent (1.3\%) strongly disagree with the item. 7 respondents $(8.9 \%)$ disagree with the item. 19 respondents (24.1\%) neither agree nor disagree with the item. 37 respondents (46.8\%) agree with the item. 15 respondents (19\%) strongly agree with the item. The mean score was 3.73 with predicate 'Strongly Affected'. It revealed that, the first item in test anxiety term strongly affected the students' anxiety in speaking.

Second, was item number 12; in speaking, I can get easily nervous if I forget things I know. From 79 respondents, 2 respondents $(2.5 \%)$ strongly disagree with the item. 8 respondents $(10.1 \%)$ disagree with the item. 25 respondents (31.6\%) neither agree nor disagree with the item. 33 respondents $(41.8 \%)$ agree with the item. The rest 11 respondents (11.9\%) strongly agree with the item. The mean score for item number 12 was 3.54 it meant the predicate of the item was 'strongly affected'. It revealed, the second item in Test Anxiety was strongly affected the students' anxiety. This item was also supported by the answer of respondent 4 "Because it feels so nervous, sometimes I have already had the sentences that I want to say, but because my friends see me, all the things just got disappeared and blank". This answer was the response of the question "What is the most disturbing thing in speaking?"

Last, was item number 3; I am so nervous when I know that I am going to be called on speaking in front of the class. From 79 respondents, 2 respondents $(2.5 \%)$ strongly disagree, 15 respondents (19\%) disagree, 22 respondents (31.6\%) neither agree nor disagree, 33 respondents (41.8\%) agree, and 11 respondents (11.9\%) strongly agree with the item. The weighted average for item number 3 was 3.35. It revealed that the item number 3 also strongly affected the anxiety of the students in speaking, and become one of the most factors that cause the most of anxiety in speaking that was experienced by the students. Along with the item, respondent 2 in interview stated that 
"almost all the time feels nervous" when the researcher asked "have you ever felt nervous or panic being called on speaking by your lecturer?"

The second highest weighted mean was Fear of Negative Evaluation. The weighted mean was 3.00. It revealed that this factor also takes part in causing students' anxiety. The interview data also confirmed that mostly respondents are afraid if they were speaking in front of their friends. They were afraid of the attention that all directed to them, some of them confirmed if they did not confident because they might commit a mistake in speaking so their friend will laugh at them. Some other confirmed that is something usual happened in the class, there were certain students took it easy, but some others lost their confident and tended to stop continuing their speaking. It had proven and supported by the detail information that the researcher got from the table result. There were two items considered as the Strongly Affected factors for the students in this part, and the rest was "Mildly Affected".

The results was like;item number 7; I keep thinking that the other students are better at language than I am. From 79 respondents, 3respondents (3.8\%) strongly disagree with the item. 8 respondents (10.1\%) disagree with the item. 22 respondents (27.8\%) neither agree nor disagree with the item. 34 respondents (43\%) agree with the item. 12 respondents (15.2\%) strongly agree with the item. The mean score was 3.56 with predicate "Strongly Affected". It indicated that, the first item in fear of negative evaluation term strongly affected students' anxiety in speaking. It became the most factor causing students' anxiety in speaking related to fear of negative evaluation, this item also supported by almost all respondent answers, because they were afraid of speaking because they should speak in front of their friend. For example respondent 1 stated "... in a group all the attention of my friends is directed to me, so when I speak all the sentences that has been created are gone. This makes me so nervous to speak". Followed by the answer of respondent 2 "I think I will make a mistake in speaking, so my friend will evaluate me as the one who currently majoring in English but still make a mistake, I feel so shy". As well as the respondent 3 and 4 also felt the same thing, but respondent 3 is the most anxious one when stated "When in a group with people who have a better capability in speaking, I feel unconfident with my ability".

Second, item number 25; I get nervous when I do not understand what the English teacher talks about. From 79 respondents, 5 respondents (6.3\%) strongly disagree with the item. 7 respondents $(8.9 \%)$ disagree with the item. 28respondents (35.4\%) neither agree nor disagree with the item. 36 respondents $(45.6 \%)$ agree with the item. 3respondents $(3.8 \%)$ strongly disagree with the item. The mean score was 3.32 with predicate "Strongly Affected". It indicated that, the second item in fear of negative evaluation term strongly affected students' anxiety in speaking.

The lowest weighted mean was Communication Apprehension. The Weighted mean was 2.90. It can be concluded that this term also took part in causing the students' anxiety. Because several respondent answered they were afraid of speaking because they were rarely speak by using English, they also afraid if they were in group with the other students that have a better ability in speaking, they felt not confident with their ability. Two respondents also revealed they did not confident in 
speaking because they did not know how to create the sentence, they did not understand the topic that was given, and also they had lack of vocabulary and did not know how to pronounce the word they should use in speaking.

There were three items considered as the strongly affected and the rest of the items was mildly affected. The result was; Item number 4; it is uncomfortable when I don't understand what the teacher is saying in English. From 79 respondents, 4respondents $(5.1 \%)$ strongly disagree with the item. 2respondents (2.5\%) disagree with the item. 22respondents $(27.8 \%)$ neither agree nor disagree with the item. 38respondents (48.1\%) agree with the item. 13respondents (16.5\%) strongly agree with the item. The mean score was 3.68 with predicate "Strongly Affected". It indicated that, the first item in Communication Apprehension term strongly affected students' anxiety in speaking.

Second, was the item number 9; I start panicking when I have to speak without preparation in English class. From79 respondents, 2 respondents (2.5\%) strongly disagree with the item. 6 respondents $(7.6 \%)$ disagree with the item. 26respondents (32.9\%) neither agree nor disagree with the item. 36 respondents (45.6\%) agree with the item. 9 respondents (11.4\%) strongly disagree with the item. The mean score was 3.56 with predicate "Strongly Affected". It indicated that, the second item in Communication Apprehension term strongly affected students' anxiety in speaking this had supported by the result of interview from respondent 3 said that she got anxious and blank if the lecturer asked her to speak without preparation.

Last, was the item number 26; I feel overwhelmed when constructing the English tenses in Speaking. From79 respondents, 1 respondents (1.3\%) strongly disagree with the item. 8 respondents $(10.1 \%)$ disagree with the item. 36respondents (45.6\%) neither agree nor disagree with the item. 30 respondents $(38.0 \%)$ agree with the item. 4respondents $(5.1 \%)$ strongly agree with the item. The mean score was 3.35 with predicate "Strongly Affected". It indicated that, the third item in Communication Apprehension term strongly affected students 'anxiety in speaking. Along with this item respondent 5 also stated that "I think how if I make a mistake in speaking like pronunciation, the structure or grammar, and I have a limited vocabulary". This answer supported that the problem in creating the structure or tense being one of the most factors that make students feel anxious.

\section{DISCUSSION}

This research tried to recognize the factors that frequently experienced by the students when they spoke English in the class and also investigated the most factors causing that anxiety in speaking. According to Hurwitz et al (1986) which are test anxiety, communication apprehension and fear of negative feedback. It was known that the majority of the students (62 out of 79) fall into mildly anxious level, which indicated that the overall level of anxiety of the Third Semester students is mildly anxious.

Based on the result of the FLCAS, it was evident that students were already anxious with the fact that they had to speak in front of the class individually. Although they had been classmates since the first semester, they had an anxiety of what was to come in the class. They experienced the same thing, i.e. they would feel anxious whenever they were asked to speak because they felt that they were unprepared and that they were not confident with their English proficiency. 
Thus it was evident that they experienced foreign language anxiety.

There are 8 items from each category in the questionnaire that had predicate "Strongly Affected" which reflect the factors that causing foreign language anxiety in speaking. There were item number 10; I worry about the consequences of failing my English class. The weighted average was 3.73. Second, it was item number 4 ; it is uncomfortable when I do not understand what the teacher is saying in English. The weighted average was 3.68 . Third, it was the item number 9; I start panicking when I have to speak without preparation in English class. The weighted average was 3.56. The fourth was item number 7; I keep thinking that the other students are better at language than I am. The weighted average was 3.56. Fifth, item number 12; in speaking I can get easily nervous if I forget the things I know. The weighted average was 3.54. Sixth, item number 3; I am so nervous when I know that I am going to be called on speaking in front of the class. The weighted average was 3.35. Seventh, item number 26; I feel overwhelmed when constructing the English tenses in speaking. The weighted average was 3.35. Last, item number 25; I get nervous when I do not understand what the teacher talks about. The weighted average was 3.32. Mostly, the factors that causing the students' anxiety in speaking class were coming from Test Anxiety,this was also supported by the data that gained from the interview, mostly respondents were afraid if they should face a condition where they had to speak in front of others or being asked by the lecturer to speak without preparation.

The second aim of this research was to find out the most dominant factor that causing students' anxiety in speaking. The researcher found from the three categories the test anxiety was the dominant factor causing the anxiety and it was reflected by the item number 10; I worry about the consequences of failing my English class. Mostly students of the third semester in English Study Program were afraid if they failed to do the test especially in speaking class. This might happen because they were afraid of making mistake while their speaking. The reasons were because they worried in committing mistake when they speak in front of others. They worried if they could not create appropriate sentences, they forgot the things that they know, or just got blank when they had prepared all the material, but because of the anxious feeling, it was feeling like they would be failed on performing their speaking.

This feeling has grown becomethe core of anxiety, when the students always feel afraid of making mistake. It because their minds could not handle the feeling itself, when the students' mind could not control their feeling, it would impact to themselves and there would be a very high intencity of negative suggestion would come to their minds. The researcher believes that those negative suggestions would worsen the anxious feeling of the students. When that anxious feeling was become worst, the fear would be greater, when the fear was greater, it would impact to the performance of the students when they speak in front of others in the class. In addition, the incapability of the students to control the fear of making mistake was because the students never realize if they were capable to control it. Therefore, it was very important to students to realize that if they could control the feeling and mind. So when they capable to do it, they could change those anxiety become a motivation. The motivation would help them to increase the capability of 
controling mind and feeling, it was also could be boosted by increasing the proficiency, the experienced, and get used to train how to control mind to minimize the anxious feeling.

Compared to previous research, this research is slightly different in many ways. Kao and Craggier (2010) found that the way that teacher conduct the class was causing the anxiety and it became the distraction for the students to improve their achievement. Mayangta (2013) found that the sources of students' anxiety in speaking English were personal and interpersonal anxiety, learners's belief about language learning, instructorlearner instructions, classroom procedures and perceived levels of English proficiency. In contrast, in this research it was found that mostly students were afraid of failing their class and making mistake while they speak.

The similarities of the research with previous studies can be found in term of results of research. Sutarsyah (2017) found that the dominant factors that caused anxiety were nervousness followed by worry and tension. He also explained that this happened because students do not believe to their performance and they felt that they have no capability in producing the target language. Then, Chan (2015) found that the most dominant factors that causing anxiety among the students was the speaking proficiency.

Moreover the researcher also found an additional factor in interview that also contributed into the anxious feeling of the students when they were performing speaking. The factor was the way the lecturer conduct the class. It was similar to Kao and Craig's research. This factor had gotten from the interview result, where one of the respondents always felt uncomfortable when the lecturer was so serious and did not try to little bit relax in the class.

This research only revealed the external factors of the students' anxiety in speaking. The data were gathered by using questionnaire. The results of the questionnaire might be inconsistent because it depends on the subject being analyzed. The subject sometime can make up their mind while answering the questionnaire, so that the result of the questionnaire tends to be bias. This research only reveals the external factors that caused foreign language anxiety in speaking. Hopefully, the further research will analyze it much deeper into the internal factors and the way how to cope with the anxiety.

Based on the discussion above, the researcher concluded that most of the third semester students of English Study Program were anxious. There are several factors that causing in speaking and mostly factors were caused by Test Anxiety. The most dominant factors that caused it were the worry feeling of consequences of failing the speaking class.

\section{CONCLUSION AND SUGGESTION CONCLUSION}

After doing the research and investigate the factors causing students' anxiety in speaking in third semester students of English Study Program, the researcher draw a conclusion based on the research question. There were two conclusions. First, there were several factors that causing foreign language anxiety in speaking, experienced by the third semester students of English Study Program in academic year 2017/2018.

1. Test Anxiety with weighted average of 3.09 (Mildly Affected)

2. Fear of Negative Evaluation with weighted average of 3.00 (Mildly Affected) 
3. Communication Apprehension with weighted average of 2.90 (Mildly Affected)

Second, the dominant factor that causing foreign language anxiety in speaking was Test Anxiety and the item number 10; I worry about the consequences of failing my English class. I worry about the consequences of failing my English class was the item with the highest weighted average score 3.73. This factor also was supported by the finding in interview, which mostly students were afraid if they made mistake and failed in their speaking class.

\section{SUGGESTION}

Based on the conclusion of this research, the researcher recommends that:

\section{For students}

This study suggested some recommended ways based on the finding and interview to reduce the possibility of anxiety in speaking. The students need to understand if anxiety is a normal feeling that experienced by everyone. They should realize if they can control that feeling by controling their mind and suggest their mind if they can cope with this feeling. So at the end they will be able to prepare themselves well. In order to make students have a better preparation before they speak in front of the class. They can improve their preparation by increasing their ability and proficiency in speaking, they also could increase their confident through having some experienced like follow the competition where speaking become the main focus, they can follow a conference where they have to communicate by using English with others, and they may follow an exchange program to live in a country where they have to survive and excercise their speaking skills.Students need to help their own selves by controlling their mind, be calm, and create a comfortable situation in the class by thinking that, if they make mistake it is something usual and should not be afraid of. Last, they need to cooperate with other students who have better capability, in order to help them improve their ability.

\section{For Lecturers}

In teaching and learning activities in the classroom. At basic, the teacher should aware if most of their students are anxious; therefore the lecturers should make a comfortable situation in teaching and learning. For example like giving more encouragement and motivation towards their students. They also need to convince the students so they will not feel worry if they make mistake, because making mistake is something common in learning. The teacher can also provide some learning styles while teaching their students, the purpose is because every students need more excercises to find their suitable way of learning. Last, the teacher can apply various learning strategies toward their students, so the students will have many choices and they will find the proper way in order to increase their capability and confident in learning English and performing a better speaking.

\section{For Further Research}

There are still manylimitations and weaknesses of the current study. Therefore, for the next research, the researcher suggest that there should be a test speaking in order to make the research becomes clearer and more detail to see the factors and symptom that causing the foreign language anxiety in speaking. The next research is also need to be more focus on the best method to reduce or cope down with the anxiety that felt by the students. It is also necessary for the next research in the future to investigate the anxiety in different skills such as writing, reading, and listening. 


\section{REFERENCES}

Abderrezag, S. (2010). The effects of Anxiety On Students' Achievement The case of third year LMD students: Department of English University of Constantine.

Arikunto,S.(2010).ProsedurPenelitian:Sua tupendekatanpraktek.Jakarta:Rineka Cipta.

Elaldi, S. (2016). Foreign language anxiety of students studying English Language and Literature: A Sample from Turkey. Academic Journal. 11(6), 219-228.

Ellis, R. (1994) Study of second language acquisition. Oxford University press.

Horwitz, E. K. (1986). Preliminary evidence for the reliability and validity of a foreign language anxiety scale. TESOL Quarterly, 20, 559-562.

MacIntyre, P. D. (1999). "Language Anxiety: A Review of Literature for Language Teachers". In D. J. Young (Ed.), Affect In Foreign Language and Second Language Learning (pp. 24 - 43). New York: McGraw Hill Companies.

MacIntyre, P. D., and Gardner, R. C. (1994). The subtle effects of language anxiety on cognitive processing in the second language. Language Learning, 44, 283-305.
Horwitz, E. K. (1991). Preliminary evidence for reliability and validity of a foreign language anxiety scale. In E. K. Horwitz\& D. J. Young (Eds.), Language anxiety:From theory and research to classroomimplications (pp. 37-40). Prentice Hall: Englewood Cliffs.

Horwitz, E. K., Horwitz, M. B., and Cope, J. (1986). Foreign language classroom anxiety. TheModern Language Journal. 70(2), 125- 132.

Kao, P., and Craigie, P. (2010). Foreign Language Anxiety and English Achievement in Taiwanese undergraduate English-major students: an empirical study.

Kayaoglu, M. M., and Saglamel, H. (2013). Students' Perceptions of Language Anxiety in Speaking Classes. Journal of History Culture and Art Research. 2(2).

Rajanthran, S., Prakash, R., and Husin, A. (2013). Anxiety levels of foreign language learners in the IEPclassroom: A Focus on NilaiUniversity's intensive English programme (IEP). Int. J. Asian Soc. Sci. 3(9):20412051

Woodrow, L. J. (2006). Anxiety and Speaking English as a Second Language. Regional Language Centre Journal, 37(3), 308-328.

Woodrow, L. J. (2006). Anxiety and Speaking English as a Second Language. RegionalLanguage Centre Journal, 37(3), 308-328. 